\title{
Meta Analisis: Variasi Penelitian Tingkat Sarjana Mahasiswa Akuntansi Universitas Medan Area
}

\section{Meta Analysis: Research Variations for Students of Undergraduate Level Medan Area University Atika Rizki}

Program Studi Akuntansi, Fakultas Ekonomi dan Bisnis, Universitas Medan Area, Indonesia

Diterima: 15 Maret 2020; Disetujui: 23 Maret 2020; Dipublish: 24 Maret 2020 Coresponding Email: atikarizki@staff.uma.ac.id

\begin{abstract}
Abstrak
Seiring dimulainya era industri 4.0 dan kecanggihan teknologi saat ini, kini penelitian akuntansi tidak terbatas pada bidang keuangan saja, namun telah muncul bidang- bidang baru dalam akuntansi dan mendorong pula perkembangan metode penelitian akuntansi. Penelitian ini bertujuan untuk memetakan dan menganalisis kecenderungan variasi penelitian skripsi mahasiswa. Penelitian ini merupakan penelitian deskriptif kualitatif. Sampel yang menjadi data dalam penelitian ini adalah penelitian skripsi mahasiswa akuntansi tingkat sarjana Universitas Medan Area untuk tahun 2019. Data dikumpulkan melalui teknik dokumentasi dari arsip digital universitas. Dengan menggunakan teknik meta analisis, data dipetakan ke dalam beberapa kategori dan sub kategori berdasarkan metode hingga bidang kajian penelitian. Hasil pemetaan menunjukkan bahwa masih banyak ditemukan penelitian yang cenderung masih menggunakan pendekatan dan bidang kajian mainstream. Hal ini dapat terlihat dari rentang jumlah penelitian yang cukup jauh dari satu sub kategori dengan sub kategori lainnya. Hasil pemetaan ini menunjukkan bahwa variasi penelitian skripsi mahasiswa akuntansi Universitas Medan Area masih cukup rendah.
\end{abstract}

Kata Kunci: Meta, Analisis, Variasi, Kajian.

\begin{abstract}
In the beginning of the industrial era 4.0 and the current technological sophistication, accounting research is now not limited to finance, but new fields have emerged in accounting and also encourage the development of accounting research methods. This study aims to map and analyze the trends of student researches variations. This research is a qualitative descriptive study. The samples that became the data in this study are the researches of the undergraduate accounting students in Medan Area University for 2019. Data is collected through documentation technique from the university digital archive. Using metaanalysis techniques, data is mapped into several categories and sub-categories based on the method to the field of research studies. The mapping results show that there are still many studies which tend to still use mainstream approaches and fields of study. This can be seen from the range of research that is quite far from one sub-category with other sub-categories. The results of this mapping show that the variation of thesis research at Medan Area University accounting students is still quite low.
\end{abstract}

Keywords: Meta, Analysis, Variation, Study.

How to Cite: Rizki, A (2020). Meta Analisis: Variasi Penelitian Tingkat Sarjana Mahasiswa Akuntansi Universitas Medan Area. Journal of Education, Humaniora and Social Sciences (JEHSS). 2 (3): 673-682. 


\section{PENDAHULUAN}

Perkembangan dan kemajuan ilmu pengetahuan tidak terlepas dari peran publikasi penelitian baik dalam jurnal akademik maupun literatur. Peran penelitian sebagai proses pengumpulan dan analisis data atau informasi yang sistematis atas suatu fenomena maupun permasalahan telah menciptakan berbagai teori dan mendukung penerapan disiplin ilmu pengetahuan. Seringkali fenomena sosial menjadi inisiasi awal dilakukannya penelitian terutama dalam bidang akuntansi.

Filosofi pendekatan dasar penelitian telah dikembangkan oleh (Burrell \& Morgan, 1979) yang mengklasifikasikan bidang kajian berdasarkan landasan teori dan filosofisnya menjadi dimensi subjektif-objektif. Penelitian akuntansi mulai berkembang pada awal abad ke-20 yang dilakukan dengan pendekatan normatif. Mayoritas tujuan dari penelitian normatif adalah untuk mengembangkan asumsi-asumsi dasar akuntansi guna menghasilkan teori-teori yang mendukung praktik akuntansi. Seiring dengan perkembangan keuangan global, penelitian akuntansi kian mengalami pergeseran. Karakteristik penelitian akuntansi normatif beralih pada penelitian yang lebih deduktif dan menggunakan analisis terstruktur hingga muncul teori akuntansi positif yang dikembangkan oleh Watts dan Zimmerman (1978) dengan pendekatan induktif. Fokus penelitian akuntansi tidak lagi bertujuan hanya untuk mengembangkan asumsi, namun lebih menekankan pada bagaimana agar informasi akuntansi dapat mempengaruhi pengambilan keputusan.

Di era industri 4.0 saat ini, penelitian akuntansi harus turut berkembang seiring dengan kecanggihan teknologi yang semakin tak terbendung. Organisasi profesi, lembaga, hingga institusi pendidikan harus berperan secara signifikan dalam memajukan penelitiam akuntansi khususnya di Indonesia. Kini penelitian akuntansi tidak terbatas pada bidang keuangan saja, namun telah muncul bidang- bidang baru dalam akuntansi di antaranya adalah sistem informasi akuntansi, akuntansi manajemen, akuntansi keperilakuan, akuntansi sosial, akuntansi syari'ah, dan akuntansi teknologi keuangan (fintech).

Meskipun secara jelas ada perkembangan dalam disiplin ilmu dan penelitian akuntansi, namun hingga saat ini masih banyak ditemukan penelitian akuntansi yang masih menggunakan pendekatan mainstream dan kurang inovatif termasuk penelitianpenelitian yang dipublikasikan dalam jurnal top akuntansi (Moser, 2012) apalagi pada 
level pendidikan tingkat sarjana di Indonesia. Bodnar dan Hopwood (2007) menjelaskan bahwa alasan mendasar dari fenomena ini adalah kurangnya wawasan, perspektif, dan inisiasi untuk melakukan kolaborasi dengan disiplin ilmu pengetahuan lainnya. Kebanyakan peneliti cenderung masih konservatif dengan mengambil sikap aman melalui topik dan bidang umum yang telah diterima secara luas.

Dalam perjalanan tren penelitian akuntansi, diperlukan adanya review sistematis dalam bentuk penelitian meta analisis agar dapat mensintesis penelitian-penelitian yang telah dilakukan sebelumnya. Meta analisis memberikan deskripsi yang komprehensif dan kuat berdasarkan literasi penelitian agar dapat menghasilkan penelitian-penelitian baru yang lebih variatif (Gough, Oliver, \& Thomas, 2012).

Beberapa penelitian sebelumnya telah melakukan meta analisis terhadap skripsi mahasiswa berdasarkan metode dan teknik analisis data (Ardhana \& Wagiran, 2007; Hutagalung \& Utomo, 2017; Pratama \& Utomo, 2018). Hasil penelitian menunjukkan bahwa mayoritas penelitian skripsi mahasiswa masih menunjukkan variasi penelitian yang rendah dalam beberapa kategori bidang meliputi metode, teknik analisis data, sumber data, maupun kesesuaian permasalahan dan analisisnya.

Penelitian ini bertujuan untuk memetakan variasi penelitian skripsi mahasiswa Universitas Medan Area selama tahun 2019. Hasil pemetaan akan dianalisis berdasarkan kategori variasi metode penelitian hingga subjek penelitian. Penelitian ini diharapkan dapat meningkatkan ruang lingkup minat dan kreatifitas penelitian mahasiswa untuk penelitian selanjutnya.

\section{METODE PENELITIAN}

Sampel dalam penelitian ini adalah penelitian skripsi mahasiswa akuntansi tingkat sarjana untuk tahun 2019 di Universitas Medan Area yang berjumlah 100 penelitian. Data dikumpulkan melalui teknik dokumentasi yang diperoleh dari arsip digital universitas. Penelitian ini termasuk ke dalam penelitian kuantitatif dalam bentuk meta analisis dengan menggunakan teknik analisis data yaitu teknik qualitative content analysis. Teknik content analysis termasuk metode analisis yang menggunakan pendekatan kualitatif dengan karakteristiknya yang sistematis dan analitis. Kompleksitas dalam proses analisisnya membutuhkan penalaran baik deduktif maupun induktif. 
Teknik ini juga menghasilkan interpretasi yang disajikan secara deskriptif dan secara statistik tidak dapat diuji.

Dengan menggunakan teknik qualitative content analysis, sampel diklasifikasikan ke dalam beberapa kategorisasi yang dijadikan sebagai acuan namun tidak kaku sehingga memungkinkan masuknya konsep-konsep atau kategorisasi baru selama proses pengumpulan data dan analisis data. Setelah sampel dikategorisasikan, sampel kemudian akan dipetakan dalam bentuk chart dan tabel serta dilakukan analisis statistik deskriptif pada akhir prosesnya. Adapun pemetaan data dilakukan dengan mengklasifikasikan data ke dalam beberapa kategori. Pertama yaitu kategori bidang kajian yang dipetakan menjadi kajian akuntansi keuangan, akuntansi perpajakan, akuntansi biaya, akuntansi manajemen, akuntansi pemerintahan, sistem informasi akuntansi, budgeting, auditing dan good corporate governance (GCG). Kedua, yaitu kategori jenis penelitian baik kualitatif maupun kuantitatif (Goddard, 2010) dimana seluruh sampel dan populasi dipetakan menjadi lima subkategori yaitu penelitian korelasi, deskriptif kuantitatif, survey, komparatif, dan eksperimen (Ulfa, 2013). Ketiga, yaitu kategori sumber data penelitian yang dipetakan menjadi tiga subkategori yaitu data primer, data sekunder, dan data gabungan (Soeratno \& Arsyad, 2008). Keempat adalah kategori teknik pengumpulan data yang dipetakan menjadi lima subkategori meliputi wawancara, observasi, studi dokumenter, kuesioner dan gabungan (Bungin, 2007). Dan terakhir yaitu kategori subjek penelitian yang dipetakan menjadi lima subkategori subjek yaitu unit/badan/lembaga pemerintahan, perusahaan swasta, bank, BUMN, dan Bursa Efek Indonesia.

\section{HASIL DAN PEMBAHASAN}

Hasil pemetaan untuk kategori bidang kajian dapat dilihat pada grafik 1 sebagai berikut:

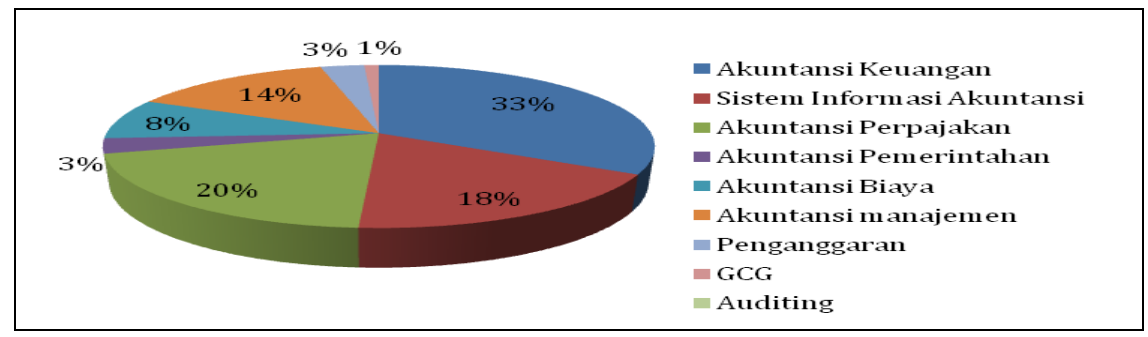

Grafik 1

Kategori Bidang Kajian 
Bidang kategori kajian yang paling banyak digunakan dalam penulisan skripsi mahasiswa di Universitas Medan Area adalah adalah akuntansi keuangan dengan persentase sebesar 33\%. Oleh karena akuntansi keuangan merupakan bidang utama dari akuntansi, maka tidak mengejutkan lagi bahwa banyak mahasiswa yang melakukan kajian penelitian di bidang akuntansi keuangan. Sebagai kajian bidang utama dari akuntansi, banyak pakar peneliti yang sudah melakukan penelitian di bidang tersebut termasuk teori-teori maupun konsep dasar yang melandasi bidang akuntansi sehingga memberikan literasi dan referensi penelitian yang sangat banyak bagi para peneliti selanjutnya. Selain itu, akuntansi keuangan mengacu pada sumber data sekunder yang saat ini telah mudah untuk diperoleh.

Kategori bidang akuntansi yang paling banyak kedua digunakan adalah akuntansi perpajakan dengan persentase sebesar 20\%. Beberapa faktor yang menjadi alasan mengapa akuntansi perpajakan banyak diminati sebagai bidang kajian penelitian di antaranya adalah bahwa akuntansi perpajakan telah lama diakui sebagai bagian dari ilmu akuntansi termasuk oleh organisasi profesi akuntansi yaitu American Accounting Association dan Ikatan Akuntansi Indonesia. Bersama dengan akuntansi keuangan dan auditing, perpajakan seringkali dianggap sebagai kajian utama dari bidang akuntansi. Selain itu, secara substansial pendapatan terbesar dari negara Indonesia untuk APBN adalah dari pendapatan pajak. Sebagai dasar perhitungan pajak, laporan keuangan adalah item yang sangat penting bagi wajab pajak. Untuk itu, baik laporan keuangan maupun laporan fiskal dan SPT merupakan data yang dapat diperoleh dengan mudah sehingga sangat membantu bagi penelitian.

Sedangkan di peringkat ketiga dengan persentase sebesar 18\% adalah bidang kajian sistem informasi akuntansi dan di peringkat keempat yaitu akuntansi manajemen dengan persentase sebesar 14\%. Mayoritas penelitian mahasiswa di bidang kajian ini mengkaitkan antara penggunaan sistem informasi akuntansi dengan kinerja manajerial. Sehingga jumlah hasil penelitian untuk kedua kategori tidak berbeda jauh hanya terpaut $4 \%$.

Empat peringkat terendah untuk bidang kajian yang diminati adalah akuntansi biaya (8\%), akuntansi pemerintahan (3\%), budgeting (3\%), dan good corporate governance (1\%). Sulitnya proses pengumpulan data menjadi faktor utama alasan rendahnya peminat dari keempat bidang kajian tersebut. Namun, yang lebih 
mengejutkan adalah bahwa tidak ada satupun penelitian untuk bidang auditing. Semakin rendahnya minat mahasiswa untuk menjadi auditor eksternal di kantor akuntan publik (Yendrawati, 2007; Sari, 2013) dapat menjadi salah satu faktor yang mendukung tidak adanya penelitian mahasiswa di bidang auditing.

Berdasarkan hasil pemetaan atas seluruh sampel menunjukkan bahwa seluruh sampel termasuk dalam jenis penelitian kuantitatif. Kecenderungan proses pengumpulan dan pengolahan data yang lebih cepat menjadi alasan mengapa metode kuantitatif banyak dipakai oleh penelitian (Ulfa, 2013). Selain itu, literasi dan referensi penelitian kuantitatif jauh lebih banyak daripada penelitian kualitatif. Kategorisasi penelitian kuantitatif diklasifikasikan lagi dalam lima kategori yang dapat dilihat pada grafik 2 sebagai berikut :

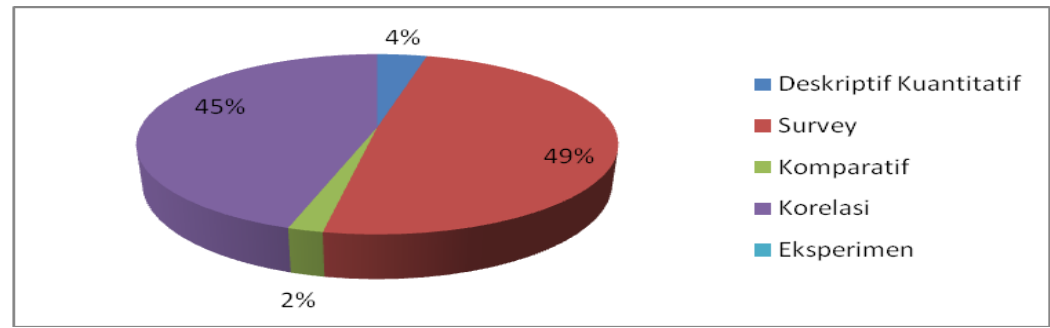

Grafik 2

\section{Kategori Penelitian Kuantitatif}

Berdasarkan kategorisasi metode kuantitatif, metode survey menjadi metode yang paling banyak digunakan dengan persentase sebesar $49 \%$ diikuti dengan metode korelasi sebesar 45\%. Hasil ini sejalah dengan kategorisasi sumber data yang digunakan yang dapat dilihat pada grafik 3 sebagai berikut:

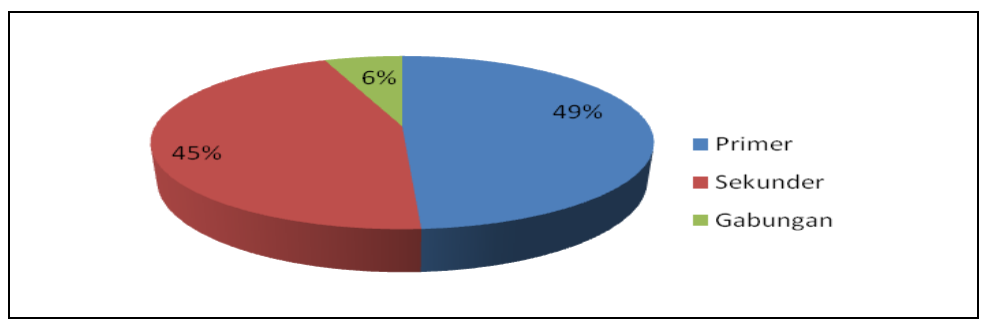

\section{Grafik 3}

\section{Kategori Sumber Data Penelitian}

Sebanyak 49\% hasil penelitian menggunakan data primer sedangkan 45\% menggunakan data sekunder. Kemudahan dalam merancang dan proses pengumpulan data, menjadikan kedua kategori baik metode survey maupun korelasi menjadi kategori yang paling banyak digunakan (Umar, 2003). Sementara itu, sulitnya unit analisis 
menjadikan komparatif dan deskriptif statistik metode yang paling sedikit digunakan yaitu masing-masing sebesar $2 \%$ dan $4 \%$. Sedangkan untuk metode eksperimen tidak digunakan oleh mahasiswa untuk penelitian. Hal ini disebabkan karena metode eksperimen adalah metode yang paling kompleks dan membutuhkan rancangan, waktu, dan biaya yang cukup besar dalam proses pelaksanaannya.

Untuk kategori teknik pengumpulan data, hasil pemetaan dapat dilihat pada grafik 4 sebagai berikut :

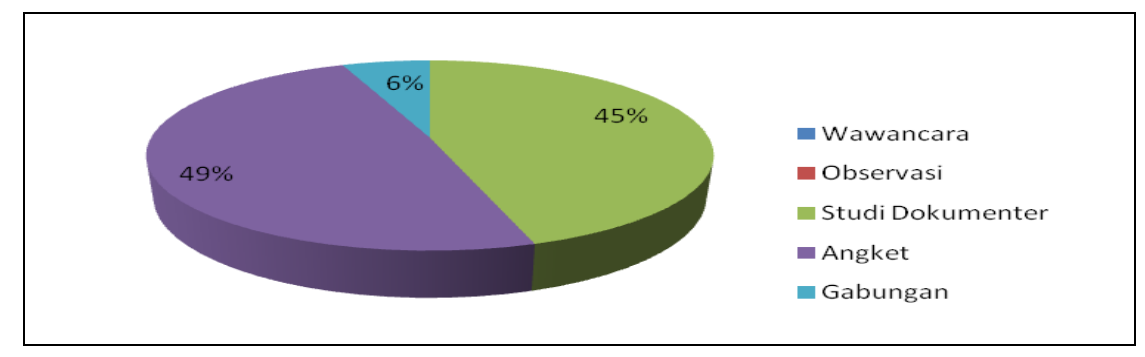

Grafik 4

\section{Kategori Teknik Pengumpulan Data}

Teknik yang paling banyak digunakan adalah angket/kuisioner dengan persentase sebesar 49\%. Meskipun biasanya membutuhkan waktu lebih lama dari studi dokumentasi dan adan ya ke mungkinan tidak kembalinya secara penuh angket/lembar kuosiner, namun teknik tersebut menjadi teknik yang paling banyak digunakan. Hal ini disebabkan karena lingkup kajian data primer dapat jauh lebih luas dari data sekunder. Ruang lingkup yang dapat dianalisis oleh teknik angket cenderung lebih dinamis dan tidak kaku seperti perilaku manajemen, penggunaan sistem, efektivitas pengendalian manajemen.

Teknik kedua terbanyak digunakan dengan persentase sebesar $45 \%$ adalah studi dokumentasi. Umumnya studi dokumentasi menggunakan data sekunder. Kemudahan dalam memperoleh data, terutama secara online seperti laporan keuangan dan laporan tahunan yang dapat diperoleh dari situs resmi Bursa Efek Indonesia, serta penggunaan biaya yang tidak mahal, menjadi alasan mengapa teknik studi dokumentasi banyak digunakan oleh peneliti. Meskipun demikian, sebanyak 6\% dari sampel menggunakan teknik gabungan antara studi dokumentasi dan teknik angket.

Untuk teknik wawancara dan observasi, tidak ada penelitian yang menggunakan masing-masing kedua teknik tersebut. Biaya yang relatif mahal, waktu yang lama, serta kesalahan dalam menafsirkan jawaban atas wawancara ataupun dalam observasi 
menjadi hambatan terbesar dalam menggunakan kedua teknik tersebut. Oleh sebab itu, untuk tingkat penelitian sarjana, teknik wawancara maupun observasi masih sulit ditemukan.

Sejalan dengan kategori penelitian kuantitatif, maka dalam analisis data sampel, sumber data penelitian diklasifikasikan dalam tiga kategori yaitu data primer, data sekunder, dan data gabungan yaitu gabungan antara data primer dan data sekunder. Sumber data yang paling banyak digunakan oleh sampel adalah data primer dengan persentase sebesar 49\%. Sedangkan data sekunder menjadi kategori kedua yang paling banyak digunakan dengan persentase sebesar 45\%. Dan sumber data yang paling sedikit digunakan adalah data gabungan dengan persentase hanya sebesar 6\%. Berikut hasil pemetaan berdasarkan kategori sumber data penelitian:

Analisis lebih lanjut, sampel diklasifikasikan berdasarkan subjek penelitian. Berikut hasil pemetaan untuk kategori subjek penelitian :

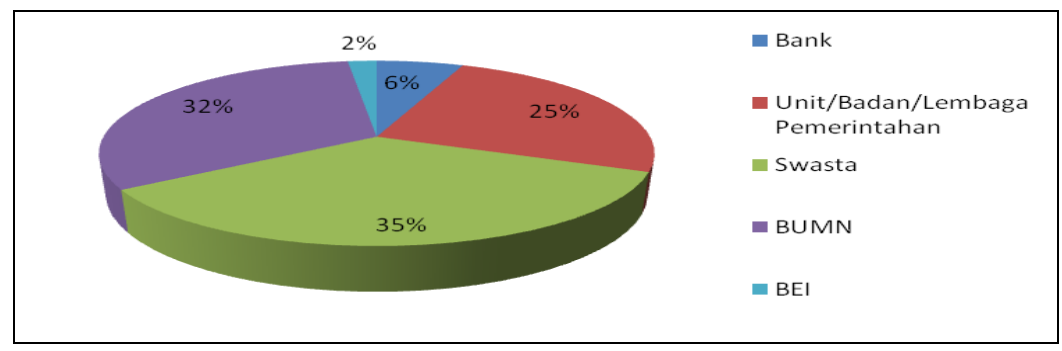

\section{Grafik 5}

\section{Kategori Subjek Penelitian}

Berdasarkan subjek penelitian, sampel diklasifikasikan ke dalam beberapa kategori yaitu unit/badan/lembaga pemerintahan, BUMN, perusahaan swasta, bank, dan Bursa Efek Indonesia. Hasil pemetaan menunjukkan bahwa perusahaan swasta paling banyak digunakan sebagai subjek penelitian dengan persentase sebesar 35\%. Sedangkan di urutan kedua, adalah BUMN dengan persentase yang tidak berbeda jauh dengan perusahaan swasta yaitu sebesar 32\%. Materi kajian bidang akuntansi yang memang bertujuan menghasilkan informasi dalam bentuk laporan keuangan menjadikan perusahaan-perusahaan yang juga diwajibkan untuk mempublikasi laporan keuangan sebagai subjek penelitian utama di bidang akuntansi.

Sementara itu, unit/badan/lembaga pemerintahan berada di peringkat ketiga sebagai subjek penelitian yang banyak digunakan sebesar 25\%. Mayoritas dari subjek penelitian di kategori ini adalah kantor pelayanan pajak. Hal ini sejalan dengan hasil 
pemetaan untuk kategori bidang kajian yang menunjukkan bahwa akuntansi perpajakan menjadi bidang kajian kedua terbanyak yang digunakan dalam penelitian mahasiswa. Sedangkan Bank dan Bursa Efek Indonesia menjadi subjek penelitian paling sedikit digunakan berdasarkan hasil pemetaan yaitu masing-masing dengan persentase sebesar $6 \%$ dan $2 \%$.

\section{SIMPULAN}

Penelitian meta analisis atas penelitian skripsi mahasiswa akuntansi Universitas Medan Area untuk tahun 2019 dilakukan dengan melakukan pemetaan berdasarkan lima kategori utama yang diklasifikasikan lagi ke dalam beberapa subkategori yaitu metode hingga kajian penelitian. Hasil penelitian menunjukkan rendahnya variasi dalam kajian penelitian baik dalam metode pengumpulan data, bidang kajian, teknik analisis data, hingga subjek penelitian.

Penelitian ini memiliki keterbatasan diantaranya adalah tidak memasukkan kategori metode analisis akuantitaif, kecenderungan landasan teori, teknik penarikan sampel, dan hanya menganalisis periode pengamatan tahun 2019. Oleh sebab itu, diharapkan penelitian selanjutnya dapat menganlisis lebih dalam mengenai variasi penelitian mahasiswa dalam skala universitas yang lebih luas, indikator yang lebih banyak, dan tren periode pengamatan yang lebih panjang.

\section{DAFTAR PUSTAKA}

Ardhana, W. S., \& Wagiran. (2007). Analisis Hasil Tugas Akhir Skripsi Mahasiswa Jurusan Pendidikan Teknik Mesin FT UNY Tahun 2005. Yogyakarta: UNY.

Bodnar, G. H., \& Hopwood, W. S. (2007). Accounting Information System. Yogyakarta: Andi.

Bungin, B. M. (2007). Penelitian Kualitatif: Komunikasi, Ekonomi, Kebijakan Publik, dan Ilmu Sosial Lainnya. Jakarta: Kencana.

Burrell, G., \& Morgan, G. (1979). Sociological Paradigms and organisational Analysis - Elements of the Sociology of Corporate Life. Sociological Paradigms and organisational analysis, 448.

Goddard, A. (2010). Contemporary public sector accounting research - An international comparison of journal papers. British Accounting Review, 42(2), 75- 87.

Gough, D., Oliver, S., \& Thomas, J. (2012). Introducing Systemic Review. UK: SagePub.

Hutagalung, T. B., \& Utomo, D. C. (2017). Meta Analisis Variasi Penelitian dari Peneliti Akuntansi Indonesia. Diponegoro Journal of Accounting, 6(4) 1-11.

McMillan, J. H., \& Schumacher, S. (2010). Research in Education. New Jersey: Pearson Education.

Moser, D. V. (2012). Is accounting research stagnant? Accounting Horizons, 26(4), 845- 850.

Pratama, K. G., \& Utomo, D. (2018). Meta Analisis Penelitian Akuntansi di Indonesia. Diponergoro Journal of Accounting, 7(4) 2337-3806.

Sari, M. (2013). Faktor-Faktor yang Mempengaruhi Pemilihan Karir Menjadi Akuntan Publik oleh Mahasiswa Departemen Akuntansi Fakultas Ekonomi UMSU Medan. Jurnal Riset Akuntansi dan Bisnis, 13(2) 174-201. 
Soeratno, \& Arsyad, L. (2008). Metode Penelitian Untuk Ekonomi dan Bisnis. Yogyakarta: Unit Penerbit dan Percetakan.

Ulfa, K. M. (2013). Pemetaan Skripsi Mahasiswa Bimbingan Dan Konseling Tahun Angkatan 2006 Fakultas Ilmu Pendidikan Universitas Negeri Surabaya. Jurnal BK, 3: 90-102.

Umar, H. (2003). Metode Riset Akuntansi Terapan. J. Appl. Sci. Environ. Manage, 11(4): 81-84.

Watts, R. L., \& Zimmerman, J. L. (1978). Towards a Positive Theory of the Determination of Accounting Standards. Accounting Review, 53(1) 112-133.

Yendrawati, R. (2007). Persepsi Mahasiswa dan Mahasiswi Akuntansi Mengenai Faktor-Faktor yang Mempengaruhi Pemilihan Karir Sebagai Akuntan. Fenomena, 5(2) 176-192. 